\title{
Simulasi Penghilangan Noise Pada Sinyal Suara Menggunakan Metode Fast Fourier Transform (FFT)
}

\author{
Muhammad Satria Adhi ${ }^{1}$, Alhamda Adisoka Bimantara ${ }^{2}$, Danang Priambodo ${ }^{3}$, \\ Hanif Muslim Azhar ${ }^{4}$, Apri Junaidi ${ }^{5}$ \\ Fakultas Teknologi Industri dan Informatika, Institut Teknologi Telkom Purwokerto \\ Jln. D.I Panjaitan No 128, Purwokerto, Jawa Tengah, Indonesia \\ ${ }_{1}^{1} 15102027 @$ st3telkom.ac.id
$215102007 @$ st3telkom.ac.id
${ }^{3} 15102013 @$ st3telkom.ac.id
${ }^{4} 15102020 @$ st3telkom.ac.id
${ }^{5}$ apri.junaidi@gmail.com \\ Accepted on April 11, 2019
}

\begin{abstract}
Perekaman suara biasa dilakukan oleh beberapa orang untuk merekam suara tertentu. Suara yang direkam tersebut biasanya memiliki informasi didalamnya yang akan ditujukan atau disampaikan kepada banyak pihak. Namun, terdapat adanya permasalahan yang sering terjadi ketika melakukan perekaman suara, yaitu adalanya noise atau gangguan suara yang menyebabkan kualitas dari hasil perekaman suara kurang baik. Permasalahan tersebut dapat diatasi dengan menerapkan metode Fast Fourier Transform untuk menghilangkan noise yang terdapat pada data suara hasil rekaman. Perhitungan dari metode Fast Fourier Transform digunakan untuk mencari nilai rata-rata dan nilai ambang batas. Selanjutnya menghilangkan nilai yang berada dibawah nilai ambang batas karena dianggap sebagai noise. Hasil dari penelitian ini merupakan menampilkan sebuah grafik yang menunjukkan data suara hasil rekaman sebelum di-filter dan sesudah di-filter.
\end{abstract}

Keywords: Fast Fourier Transform , Noise, Suara

\section{INTRODUCTION}

\section{$\mathbf{P}$} ada zaman modern sekarang ini teknologi sudah semakin pesat berkembang, berbagai alat canggih dibuat untuk memenuhi kebutuhan manusia. Setiap peralatan elektronik sekarang ini sudah menggunakan sinyal untuk mengirim dan menerima data. Salah satunya adalah sinyal suara. Sinyal suara banyak digunakan kebutuhan seperti berkomunukasi, merekam musik, sound effect, dan lain sebagainya. Namun terkadang sinyal suara yang diterima tidak sesuai yang diinginkan seperti suara noise dan putus-putus, gangguan sinyal suara ini bisa terjadi karena cuaca yang mengganggu sinyal, sinyal terhalang oleh suatu bangunan dan lainlain.

Untuk mengurangi masalah tersebut, peneliti melakukan penelitian ini yang bertujuan untuk mempelajari dan mensimulasikan cara mengolah sinyal suara, yang nantinya bisa digunakan dalam sebuah microphone agar nantinya sinyal suara yang didapat lebih stabil dan kuat sehingga minim gangguan. 
Dimana proses dan perancangan program dalam simulasi ini dikerjakan melalui aplikasi MATLAB. Dalam proses pemfilteran sinyal pada sistem ini menggunakan metode Fast Fourier Transform (FFT) sebagai metode yang mentransformasikan sinyal suara dalam domain waktu (s) menjadi sinyal suara dalam domain frekuensi (Hz).

\section{LITERATURE REVIEW}

Penelitian tentang "Audio Watermarking Dengan Menggunakan Metode Fast Fourier Transform (FFT) dan Singular Value Decomposition (SVD)" yang dilakukan oleh Robinzon Pakpahan tentang audio watermarking mennghasilkan sebuah rancangan program yang dapat melakukan penyisipan suatu citra pada sebuah data audio dengan menggunakan Fast Fourier Transform (FFT) dan Singular Value Decomposition (SVD) dengan Quantization Index Modulation (QIM) sebagai metode embedding, sehingga dengan metode tersebut sistem akan memiliki kelebihan terhadap robustness dan kapasitas data yang dapat disisipkan. Kemudian hasil dari audio Watermarking didapatkan hasil performansi dengan mencapai nilai tertinggi BER 0\% pada 5 jenis host audio yang berbeda, namun untuk nilai SNR mencapai nilai tertinggi 69db sehingga hasil audio terWatermark maksimal, dan untuk nilai SSIM mencapai nilai maksimal [1]

Nanda Pradipta melakukan penelitian berjudul Implementasi Algoritma Fast Fourier Transfrom (FFT) pada Digital Signal Processor (DSP) TMS320C542. DSP atau Digital Signal Processor merupakan salah satu tipe dari mikroprosesor yang mempunyai kemampuan yang relatif besar dengan kecepatan yang relatif tinggi. DSP digunakan di berbagai produk elektronika, misalnya telepon selular dan modem. Salah satu aplikasi dari DSP adalah untuk membuat algoritma Fast Fourier Transform (FFT). Fast Fourier Transform (FFT) merupakan metode perhitungan Dicrete Fourier Transform (DFT) yang sangat efisien sehingga akan mempercepat proses perhitungan DFT. Penelitian ini bertujuan mengimplementasikan algoritma Fast Fourier Transform (FFT) pada Digital Signal Processor TMS320C542 menggunakan DSP Starter Kit, DSKplus. Program utama algoritma FFT terdiri dari proses pembalikan bit, algoritma kupu-kupu dan perhitungan magnitude. Program utama ini juga memanggil file inisialisasi berekstensi .asm yang telah dibuat yaitu inisialisasi vektor interupsi, inisialisasi AIC, dan inisialisasi koefisien twiddle. Program perhitungan FFT ini menggunakan algoritma FFT radiks-2 dengan metode DIT. hasil implementasi telah sesuai dengan teori, yaitu pada sinyal sinus hanya terdapat frekuensi fundamental saja, sedangkan pada sinyal segitiga dan sinyal kotak terdapat frekuensi fundamental dan frekuensi harmonisa yang muncul pada kelipatan ganjil dari frekuensi fundamental [2].

Sipasulta,dkk melakukan penelitian mengenai pengecekasn sebuah sinyal suara sehingga informasi yang ingin disampaikanhanya dapat diterima oleh tujuan yang diinginkan oleh user. Dalam melakukan perkaman suara dibutuhkan alat input microphone internal dari PC. Metode yang digunakan pada penelitian tersebut adalah Fast Fourier Transform untuk mengacak dan mentransformasikan sinyal suara dalam domain waktu menjadi sinyal suara dalam domain frekuensi. Tahap awal pada penelitian tersebut adalah melakukan perekaman suara. Setelah tahap perekaman suara selesai, selanjutnya melakukan pengacakan sinyal untuk membuat informasi yang pengguna kirimkan tidak dapat didengar oleh siapapun selain tujuan yang dituju oleh pengguna. Berdasarkan pengujian yang dilakukan pada penelitian tersebut, sistem yang dibuat dapat mengacak semua jenis suara yang direkam dalam interval waktu 3 detik. Hasil dari penelitian ini adalah sebuah program/sistem yang dijalankan melalui MATLAB [3].

Harahap, dkk melakukan penelitian mengenai Implementasi Teknik Watermarking menggunakan FFT dan Spread Spectrum Watermark pada Data Audio Digital. Penelitian tersebut dilandasi sebuah permasalahan yaitu banyaknya pemalsuan dan penyebaran yang tidak sah terhadap data digital. Sehingga diperlukan sebuah teknologi yang dapat melindungi hak cipta data multimedia seperti audio. Metode yang digunakan dalam penelitian tersebut adalah Fast Fourier Transform. Metode tersebut dapat mengubah data audio asli ke dalam domain frekuensi sebelum dilakukan proses penyisipan watermark dan proses ekstrasi watermark. Teknik watermarking pada penelitian tersebut menghasilkan Signal-to -Noise Rasio diatas $20 \mathrm{~dB}$ dan Bit Error Rate di bawah $5 \%$ [4]. 


\section{RESEARCH METHOD}

Pada penelitian ini terdapat beberapa tahapan yang akan dilakukan oleh peneliti dalam melakukan penelitian sebagai berikut :

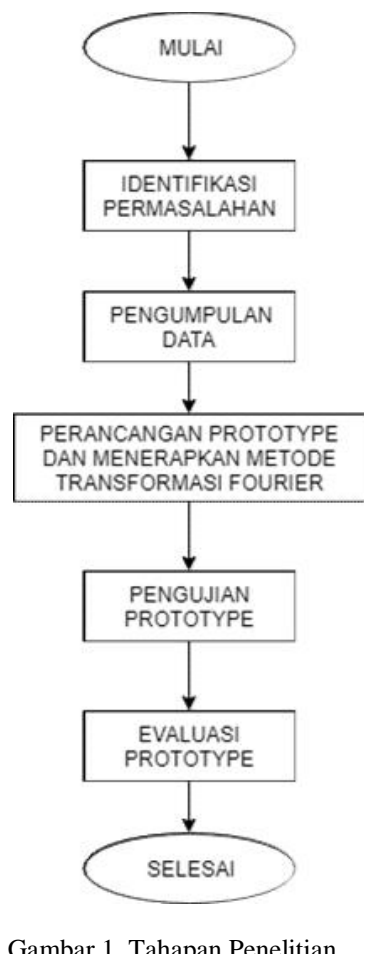

Gambar 1 menunjukkan alur dari tahapan-tahapan penelitian yang dilakukan oleh peneliti, berikut adalah penjelasan dari setiap tahapan-tahapan penelitian tersebut.

1. Identifikasi Permasalahan

Pada tahap awal penelitian ini, peneliti menemukan sebuah permasalahan mengenai data audio. Permasalahan yang sering terjadi pada data audio merupakan adanya noise atau gangguan suara ketika melakukan perekaman suara yang menyebabkan turunnya kualitas dari data suara yang dihasilkan. Noise yang muncul saat melakukan rekaman suara biasanya terjadi karena adanya suara-suara di lingkungan sekitar, angin yang terhembus kearah microphone, dan gangguan suara lainnya. Dengan adanya permasalahan tersebut, peneliti melakukan penelitian dengan tujuan untuk menyelesaikan permasalahan adanya noise pada data suara hasil dari rekaman suara dengan metode yang digunakan pada penelitian ini.

2. Pengumpulan Data

Data yang dibutuhkan pada penelitian ini adalah berupa data suara hasil rekaman. Media yang digunakan untuk melakukan rekaman adalah melalui Handphone. Selain menggunakan Handphone, peneliti juga menggunakan rekaman menggunakan laptop dengan cara menulis program di MATLAB untuk melakukan perekeman suara. Suara yang sudah direkam kemudia disimpan dalam format wav di folder tertentu. Nantinya hasil rekaman tersebut akan dibaca dengan program di MATLAB untuk diuji.

3. Kebutuhan Perangkat Keras dan Perangkat Lunak

Peneliti dalam melakukan penelitian ini menggunakan spesifikasi kebutuhan perangkat lunak dan perangkat keras sebagai berikut : 
a. Kebutuhan perangkat lunak

1. Sistem operasi Windows 10 Professional x64 bit

2. Matlab R20016a

b. Kebutuhan perangkat keras

1. HP BW073AX Processor: AMD A12-9720P Quad-Core @ 2.7 Ghz x64

2. RAM 8 GB DDR4 $1866 \mathrm{Mhz}$ Single Channel

3. Harddisk 1 TB 5400 RPM

4. Perancangan Prototype dan Penerapan Metode Fast Fourier Transform

Tujuan dari perancangan prototype ini adalah untuk membuat sebuah program yang memiliki fungsi untuk menghilangkan atau meminimalisir noise yang ada pada data suara hasil rekaman. Program pada penelitian ini menerapakan perhitungan Fast Fourier Transform untuk menghilangkan noise.

Fast Fourier Transform (FFT) adalah suatu algoritma yang digunakan untuk menghitung transformasi fourier diskrit dengan cepat dan efisien [3]. Persamaan FFT ditunjukkan pada Persamaan 1 dibawah ini.

$S(f)=\int_{-\infty}^{\infty} s(t) e^{-j 2 \pi \zeta \iota} d t$

Dimana $\mathrm{s}(\mathrm{f})$ adalah sinyal dalam domain frekuensi (frequency domain), $\mathrm{s}(\mathrm{t})$ adalah sinyal dalam domain waktu (time domain), dan adalah konstanta dari nilai sebuah sinyal, f adalah frekuensi dan $\mathrm{t}$ adalah waktu.

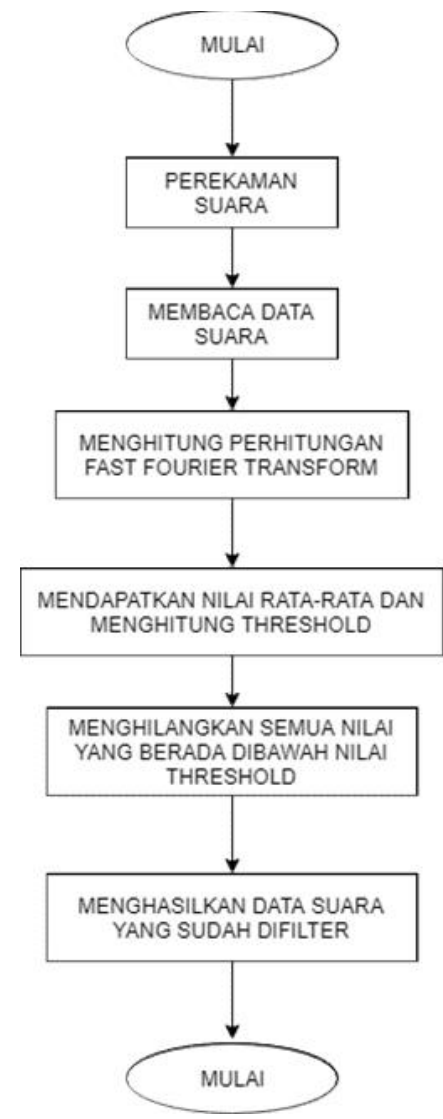

Gambar 2. Diagram Alur Proses Sistem 
Alur proses pada sistem diawali dengan melakukan perekaman suara menggunakan sistem tersebut. Setelah mendapatkan data suara, selanjutnya data tersebut disimpan di folder tertentu. Data suara hasil rekaman tersebut akan dibaca oleh sistem untuk dihilangkan noise dengan menerapkan perhitungan Fast Fourier Transform. Dari hasil perhitungan tersebut didapatkan sebuah nilai rata-rata dan nilai ambang batas atau Threshold. Selanjutnya menghilangkan semua nilai yang berada dibawah nilai ambang batas. Hal tersebut dilakukan karena peneliti beranggapan semua nilai yang berada dibawah nilai ambang batas merupakan sebuah noise. Pada tahap akhir, sistem akan menghasilkan sebuah data suara baru yang memiliki kualitas yang lebih baik dibandingkan dengan data suara sebelumnya.

\section{Pengujian Prototype}

Setelah prototype dibuat dan dapat digunakan, selanjutnya adalah melakukan pengujian terhadap prototype tersebut. Tujuan dari tahap pengujian ini adalah untuk mengetahui apakah prototype tersebut dapat berjalan dengan baik sesuai dengan yang diharapkan. Apabila sistem berjalan dengan baik, maka sistem akan menampilkan sebuah grafik data suara rekaman asli dan data suara hasil dari penerapan metode Fast Fourier Transform untuk menghilangkan noise.

\section{RESUlTS AND DiSCUSSION}

Tahapan pertama yang dilakukan pada penelitian adalah mengumpulkan data suara yang diambil atau direkam menggunakan microphone pada handphone dan laptop. Sampel suara yang digunakan pada penelitian ini sebanyak tiga sampel. Sampel tersebut disimpan kedalam file berformat WAV yang kemudian sinyal suara tersebut ditampilkan dalam bentuk grafik pada program MATLAB.

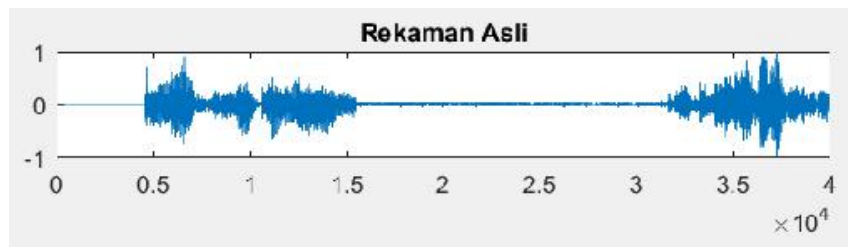

Gambar 3. Grafik Sampel Suara

Dengan menggunakan metode FFT, sinyal suara yang berisi noise tersebut akan dihilangkan. Untuk penerapan metode FFT menggunakan fungsi atau perintah yang sudah disediakan oleh MATLAB. Kemudian akan didapatkan hasil berupa sinyal suara yang telah dihilangkan noise. Sinyal suara tersebut ditampilkan dalam bentuk grafik.

Pengujian pertama dilakukan pada sampel suara yang berbunyi "halo selamat malam semua" dengan noise bunyi mesin kipas angin. Gambar 3 menunjukan sinyal suara sebelum dan sesudah penerapan metode FFT.

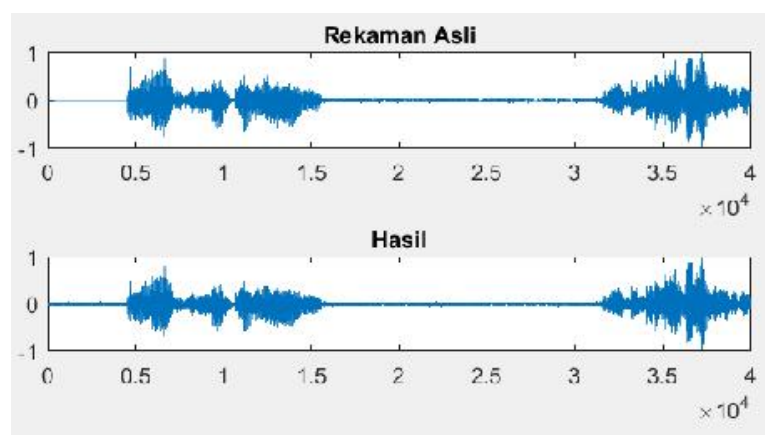

Gambar 4. Grafik Hasil Pengujian Sampel 1 
Dari gambar 4 tersebut dapat dilihat bahwa dilakukan reduksi pada sinyal suara rekaman asli dimana terjadi pengurangan nilai frekuensi. Kemudian dilakukan pengujian pada sampel suara yang diambil pada kondisi ramai seperti ditunjukkan pada Gambar 5.

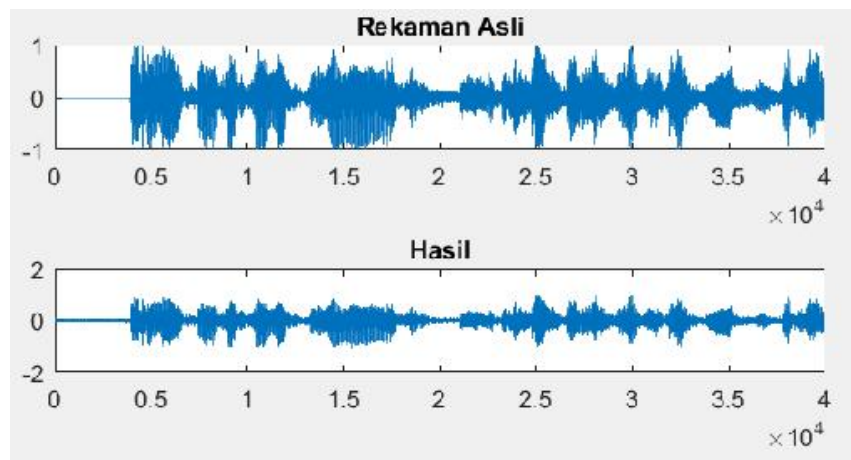

Gambar 5. Grafik Hasil Pengujian Sampel 2

Pada Gambar 5 dapat dilihat bahwa terjadi perbedaan nilai frekuensi yang sangat mencolok setelah dilakukan penghilangan noise dengan metode FFT. Sebagian noise pada sampel tersebut menjadi agak berkurang dan suara dapat didengar jelas.

\section{Conclusion}

Berdasarkan pengujian yang telah dilakukan dapat disimpulkan bahwa metode Fast Fourier Transform (FFT) dapat diterapkan untuk menghilangkan atau meminimalisir noise pada sinyal suara. Metode FFT dapat menghilangkan noise seperti noise yang disebabkan oleh suara angin dan keramaian.

Pada penelitian ini program yang dibuat masih sangat sederhana oleh karena itu diharapkan penelitian selanjutnya yang mengembangkan program ini lebih lanjut dengan menambahkan fitur-fitur lainnya.

\section{ACKNOWLEDGMENT}

Terima kasih sebesar-besarnya untuk Bapak Apri Junaidi, M.Kom., M.Cs selaku dosen mata kuliah Pengenalan Suara yang telah membimbing pada penelitian ini.

\section{REFERENCES}

[1] R. Pakpahan, R. D. Atmaja, and S. Saidah, "Audio Watermarking Dengan Menggunakan Metode Fast Fourier Transform (FFT) Dan Singular Value Decomposition (SVD)," e-Proceeding Eng., vol. 5, no. 2, pp. 2017-2022, 2018.

[2] N. Pradipta, "Implementasi Algoritma FFT (Fast Fourier Transform) Pada Digital Signal processor (DSP) TMS320C542," Universitas Diponegoro, 2014.

[3] R. Y. Sipasulta, A. S. M. L. St, and S. R. U. A. Sompie, "Simulasi Sistem Pengacak Sinyal Dengan Metode FFT ( Fast Fourier Transform )," E-Journal Tek. Telektro dan Komput., pp. 1-9, 2014.

[4] H. Harahap, G. Budiman, and L. Novamizanti, "Implementasi Teknik Watermarking menggunakan FFT dan Spread Spectrum Watermark pada Data Audio Digital," J. ELKOMIKA, vol. 4, no. 1, 2016. 